\title{
Phonological and Semantic Verbal Fluency Tasks in a Sample of Argentinean Children
}

\author{
Julieta Fumagalli ${ }^{1}$ \\ CONICET - Universidad de Buenos Aires, Facultad de Filosofia y Letras, \\ Instituto de Lingüistica, Buenos Aires, Argentina \\ Federico Soriano \\ Instituto de Neurociencias Cognitiva y Traslacional (INCyT), Buenos Aires, Argentina \\ Diego Shalóm \\ CONICET, IFIBA, Facultad de Ciencias Exactas y Naturales, Universidad de Buenos Aires \\ Juan Pablo Barreyro \\ CONICET - Departamento de Investigación en Procesos Básicos, \\ Instituto de Investigaciones Facultad de Psicología/UBA, Buenos Aires, Argentina \\ María Macarena Martínez-Cuitiño \\ Laboratorio de Investigaciones en Lenguaje, Instituto de Neurociencia Cognitiva \\ y Traslacional (INCyT), Ineco/Favaloro/Conicet, Buenos Aires, Argentina
}

\begin{abstract}
The aim of this work is to obtain data about the evolutionary pattern of performance in verbal fluency tasks for a sample of Argentinean primary school aged children $\left(3^{\text {rd }}, 5^{\text {th }}\right.$ y $7^{\text {th }}$ grade $)$ in semantic and phonological verbal fluency tasks. For the semantic fluency task, children were assessed in different categories: animals, fruits and vegetables, and body parts for living things domain, and means of transport, musical instruments and clothes for inanimate objects. For the phonological fluency assessment, children were tested with /f/, /a/ and /s/ phonemes. Both fluency tasks showed differences between grades, indicating the influence of education. Besides, irrespective of the grade, children performed better on the semantic fluency tasks. Results in the semantic fluency task also showed a better performance for the living things domain over the inanimate objects domain. Further analysis on the results showed that $3^{\text {rd }}$ grade children have the worst performance, compared to $5^{\text {th }}$ and $7^{\text {th }}$ grade children. The results of our work are discussed taking in account cognitive mechanisms, executive functions and semantic memory development.
\end{abstract}

Keywords: Semantic fluency, phonological fluency, educational status, children.

\section{Fluência Semântica e Fonológica em uma Amostra de Crianças Argentinas}

\section{Resumo}

No presente trabalho oferecemos dados de tarefas de fluência verbal para crianças argentinas de $3^{\circ}, 5^{\circ} \mathrm{e}$ $7^{\circ}$ ano do ensino fundamental. Os participantes foram avaliados com uma tarefa de fluência semântica, que testou as categorias de animais, frutas e legumes e partes do corpo para o domínio dos seres vivos e meios de transporte, instrumentos musicais e roupas para os objetos inanimados. As crianças também foram avaliadas com uma tarefa de fluência fonológica que testou os fonemas /f/, /a/ e /s/. Os dados obtidos apontam para diferenças de desempenho entre as tarefas e mostraram um melhor desempenho

Mailing address: 25 de Mayo, 217/221, $1^{\circ}$ piso, (C1002ABE) Ciudad Autónoma de Buenos Aires, Buenos Aires, Argentina. Phone: (+54 11) 4342-9710/9718, int. 103. E-mail: fumagallijulieta@gmail.com 
nas de fluência semântica. Além disso, nas tarefas de fluência semântica os participantes tiveram um melhor desempenho no domínio dos seres vivos. Tanto para fluência semântica quanto fonológica, as diferenças estiveram presentes quando os grupos foram comparados pelo nível de escolaridade, de modo que os alunos de $3^{\circ}$ ano se dissociam significativamente dos $5^{\circ}$ e $7^{\circ}$ anos, produzindo menor quantidade de exemplares. Os resultados são discutidos à luz de possíveis diferenças originadas no desenvolvimento cognitivo, as funções executivas e o sistema semântico.

Palavras-chave: Fluência semântica, fluência fonológica, nível de escolaridade, crianças.

\section{Fluidez Verbal Semántica y Fonológica en una Muestra de Niños de Argentina}

\section{Resumen}

El objetivo del presente trabajo es obtener información del patrón evolutivo de desempeño en tareas de fluidez verbal para una muestra de niños argentinos de nivel primario de $3^{\circ}, 5^{\circ}$ y $7^{\circ}$ grado. Se evaluó a los participantes con una tarea de fluidez semántica, en la que se evaluaron las categorías de animales, frutas y verduras, y partes del cuerpo para el dominio de seres vivos, y medios de transporte, instrumentos musicales y ropa para el de objetos inanimados. Asimismo fueron evaluados con una tarea de fluidez fonológica en la que se testearon los fonemas $/ \mathrm{f} /, / \mathrm{a} / \mathrm{y} / \mathrm{s} /$. Los datos obtenidos dan cuenta de diferencias de rendimiento entre las tareas de fluidez con un mejor desempeño en las tareas de fluidez semántica. Asimismo, en las tareas de fluidez semántica se observa un mejor rendimiento en el dominio de seres vivos. Las diferencias obtenidas en ambas tareas se identifican al comparar los grupos según escolaridad, siendo únicamente los niños de $3^{\circ}$ grado los que, con menor cantidad de ejemplares recuperados, se disocian significativamente de $\operatorname{los}$ de $5^{\circ}$ y $7^{\circ}$ grado. Estos hallazgos son discutidos a la luz de posibles diferencias en función del desarrollo cognitivo, de las funciones ejecutivas y del sistema semántico.

Palabras claves: Fluidez semántica, fluidez fonológica, escolaridad, niños.

Verbal fluency measurements are frequently used in neuropsychological research and clinical practice, as they are easy and quick to administrate, but also because of the high degree of reliability their results have for diverse pathologies (Fernández, Marino, \& Alderete, 2004; Henry \& Crawford, 2004; Henry, Crawford, \& Phillips, 2004). In a verbal fluency test, participants are asked to provide as many examples as possible for one or several categories in a certain amount of time, for example, in one minute (Lezak, Howieson, \& Loring, 2004). There are two variants of the verbal fluency tests: semantic verbal fluency (SVF) and phonological verbal fluency (PVF). In the first, the participants must look for as many examples as possible of a specific semantic category (for example, animals or fruits). In the PVF, the participants are asked to indicate as many words as possible that begin with a certain sound (for example, $/ \mathrm{p} /$ or $/ \mathrm{s} /$ ).
In verbal fluency tasks, diverse cognitive mechanisms are brought into play for the task: working memory, sustained attention, executive functions, semantic memory, search and recovery strategies for lexical items, among others. Because of this, verbal fluencies are very sensitive measurements when it comes to evaluating cognitive plasticity and organization strategies (Henry \& Crawford, 2004; Lezak et al., 2004; Stuss et al., 1998). Even though both tasks require executive demands (Hirshorn \& Thompson-Schill, 2006), word recovery in the SVF is based on semantic associations and the meaning of each one of them, while the PVF implies strategies that are not typically used and which require more effort (Hurks et al., 2006).

Both SVF and PVF are useful tools to diagnose certain neurological pathologies. SVF results are highly sensitive for research into degenerative diseases (Lezak et al., 2004). The 
scores in this type of task are used to diagnose early onset Alzheimer's and are an important predictor of Parkinson's Disease and other types of dementia like vascular dementia, the semantic variant of Frontotemporal Dementia or subcortical dementia; likewise, they are useful to identify patients with Huntington's Disease or ones with psychiatric conditions like schizophrenia (Binetti et al., 1995; Chertkow \& Bub, 1990; Galaverna, Marino, \& Abraham, 2008; Hodges \& Patterson, 1997; Rosser \& Hodges, 1994). Patients will specifically fail when they have problems maintaining attention; this is caused by difficulties in the frontal lobe or when they cannot recover examples due to alterations in the temporal lobe. Patients with focal frontal lesions have difficulties in the $\mathrm{PVF}$, as they cannot properly use the cognitive mechanisms needed to make the searches, start the responses and perform the monitoring. Patients with temporal difficulties will have problems with the SVF, as they cannot choose or suitably group the examples of different categories evaluated due to difficulties in the semantic memory (Troyer, Moscovitch, Winocur, Alexander, \& Stuss, 1998).

Diverse studies have shown that some demographic and social variables have an impact on test performance, with age and the educational level reached by subjects being the two most important variables (Kempler, Teng, Dick, Taussig, \& Davis, 1998). Some studies have shown that the results in verbal fluency tests proportionally improve with age (Casals-Coll et al., 2013; Fernández et al., 2004; Kempler et al., 1998; Lezak et al., 2004; Lozano Gutiérrez \& Ostrosky-Solís, 2006; Ollari \& Diez, 2005; Pekkala et al., 2009). However, there are studies with elderly people that demonstrate the existence of an inflection point (from the sixth decade onwards), where the performance begins to decrease as the age rises. It has even been shown that performance falls more in men than in women (Rodríguez-Aranda \& Martinussen, 2006). Educational status is especially important for the PVF tests (Ratcliff et al., 1998). Another socio-demography variable to bear in mind is gender. The studies that are available show contradictory results. In some cases, gender represented a significant variable in the distribution of the results (Capitani, Laiacona, \& Barbarotto, 1999; Laws, 1999, 2004; Marino \& Alderete, 2010; Marra, Ferraccioli, \& Gainotti, 2007; McKenna \& Parry, 1994; Soriano et al., 2015) while, in others, it had no impact or this was only relative (Casals-Coll et al., 2013; Fernández et al., 2004). In general, women have a better performance than men in verbal fluency tasks (Halpern, 1992). In regards to semantic fluency, there are differences but, overall, women are better at the fruit/vegetable and furniture categories and men with animals and tools (Albanese, Capitani, Barbarotto, \& Laiacona, 2000).

There has been little verbal fluency task research performed with native Spanish speakers if we compare them, for example, to those done in English (Tombaugh, Kozak, \& Rees, 1999). There have been studies done on the Mexican (Ostrosky-Solís \& Ardila, 1991), Colombian (Ramírez, Ostrosky-Solís, Fernández, \& ArdilaArdila, 2005) and Spanish populations (Buriel, Gramunt, Bohm, Rodes, \& Pena-Casanova, 2004; Villodre et al., 2006). For Argentina, there are some specific studies (Comesaña \& García Coni, 2013; Fernández et al., 2004; Marino \& Alderete, 2010; Villodre et al., 2006; Zanin, Ledezma, Galarsi, \& De Bortoli, 2010).

The verbal fluency tasks, both SVF and PVF, have also been applied to child populations. The results of tests on children have been used in studies on attention deficit disorder, Turner's syndrome, development dyslexia, among others. The PVF test is especially sensitive for detecting children that have Attention Deficit Hyperactivity Disorder (Hurks et al., 2004).

There are several studies about child populations in fluency tasks, most of them performed on Spanish children (Nieto, Galtier, Barroso, \& Espinosa, 2008), but it is also possible to find some research done in Argentina (Arán-Filippetti, 2011; García Coni \& Vivas, 2014; Marino \& Díaz-Fajreldines, 2011). Most interest in child verbal fluency studies comes from the fact that these tasks evaluate cognitive mechanisms that are still being developed, giving a clearer per- 
spective about the ontogenesis of these mechanisms. In this sense, sociodemographic variables are extremely important since they shed light on the development periods of specific cognitive abilities. In research with children, it has been seen that age is without a doubt the most relevant variable. Verbal fluency increases in infancy and during adolescence (Matute, Rosselli, Ardila, \& Morales, 2004). SVF increases mainly in children between 8 and 11 (Lozano Gutiérrez \& Ostrosky-Solís, 2006) and seems to be related with a progressive development of semantics in language. In the same way, the increase in PVF tasks is lower than in the SVF tasks (Koren, Kofman, \& Berger, 2005).

Nevertheless, it is still not possible to indicate at what moment children's performance in these tests reaches adults'. Some research projects report that children at age 10 reach a similar performance to that of adults (Anderson, Northam, Hendy, \& Wrenall, 2001), while others indicate that this occurs in adolescence or early adulthood (Klenberg, Korkman, \& LahtiNuuttila, 2001). Some research dissociates the performance of children in SVF and PVF. The performance of children in PVF would reach adult levels later than in SVF, where similar levels to those of adults would be reached between 14 and 15 (Matute et al., 2004). Other studies made on infant populations have positively correlated the performance of the subjects, even at school age, with the educational level reached by the parents (Ardila, Rosselli, Matute, \& Guajardo, 2005).

Until nowadays there is still no accurate data about the performance pattern of school-age children in verbal fluency tasks, this work aims to get to know the evolutionary performance pattern in PVF and SVF of primary education-aged Spanish-speaking children in Argentina. For the SVF, data was obtained from several semantic categories (animals, fruit and vegetables, parts of the body, clothing, musical instruments and transports) to obtain a more accurate measurement of the semantic progression of language. In regards to PVF, data was obtained on the phonemes, F, A and S, as these fluencies constitute a research tool that is universally used in clinical assessment.

\section{Methodology}

\section{Participants}

A sample of 86 children participated in the research. 32 children from $3^{\text {rd }}$ grade $(40.6 \%$ boys) with a mean age of $8.58(S D=.38), 25$ students from $5^{\text {th }}$ grade ( $40 \%$ boys) with a mean age of $10.70(S D=.41)$; and 29 from $7^{\text {th }}$ grade (44.8\% boys) with a mean age of 12.54 (SD = .43). All the participants were native Spanish speakers and had no sensorial deficit, neurological alterations or learning difficulties that had been diagnosed at the time of the evaluation. All the children assessed attended a private school with an average socioeconomic level from the city of Buenos Aires. The parent's educational and occupational level was taken into account to establish the participant's socioeconomic level. According to Sautú (1991), at least one of the parents must have reached tertiary or university level education to be included in this socioeconomic group. This criterion was considered for the selection of the sample. The participants voluntarily answered the test and they had not only the authorization of their parents and guardians, but also from the General Education Planning Direction of the Government of the City of Buenos Aires for the evaluation.

\section{Procedure}

The students from each grade were individually assessed with a PVF task and a SVF task in a single session by one of the researchers during September 2014. The assessment was performed during classroom hours in a classroom provided by the institution for this purpose.

Both tests were taken together, with the participants first answering the PVF task and then, the SVF one.

The assignment for the first task was as follows: "Please state, in one minute, all the words that come to your mind, that begin with the following phoneme, with no proper names, for example M". The participants answered for the phonemes, F, A and S. Before the evaluation, it was checked whether the children had understood the assignment and two test phonemes, $\mathrm{P}$ 
and $\mathrm{M}$, were proposed. Once we were sure that they could do the task, the evaluation began. Once the PVF evaluation had ended, the SVF evaluation was done with the following assignment: "Now, I am going to ask you to tell me, in one minute, all the words that come to your mind about the different categories I am going to tell you, for example, professions". The children answered on categories about living things domain (LT; animals, fruit/vegetables and body parts) and inanimate objects domain (IO; clothing, musical instruments and transports). Once again, two test categories were used as examples (professions and sports) to be clear that they had understood the task. The responses for both tasks were recorded on a digital recording device.

A person then had the role of transcribing the responses of the children, word by word. However, only the names of examples of the categories were considered as valid responses for semantic fluencies. Words that indicate the same exemplar (for example, lion - lioness) were eliminated; superordinate categories were not accepted (for example, fishes). Variations of the same response were grouped into one (for example, green apples, red apples were grouped as apples). Errors from a specific category were removed (for example, dog from the category musical instruments). For phonological fluency, proper nouns or family names were not counted (bitch, hound, puppy, etc.). Repetitions were eliminated both in SVF and PVF.

\section{Statistical Analysis}

In order to identify possible performance differences in the semantics and phonological fluency tasks of Spanish speaking school-age children in Argentina, a mixed variance analysis was done using a $2 \times 3$ ANOVA, taking (phonological and semantic) fluency as intrasubject variables and the grades $\left(3^{\text {rd }}, 5^{\text {th }}\right.$ and $\left.7^{\text {th }}\right)$ as intersubject variable.

A second analysis was done to identify possible differences in the processing of LT and IO semantic domains. For this, another $2 \times 3$ mixed variance ANOVA analysis was applied. The domain (LT vs. IO) was taken as intrasubject variable and the grade $\left(3^{\text {rd }}, 5^{\text {th }}\right.$ and $\left.7^{\text {th }}\right)$ as intersubject variable. The size of the effect for both analysis types was calculated from the partial Eta squared $\left(\eta^{2}\right)$.

\section{Results}

The performance of the different grades in the phonological and semantic fluency tasks is shown in Table 1, below. The scores presented in this table show the mean average of the examples given by the participants for each semantic category evaluated in the semantic fluency task and for each phoneme evaluated in the phonological fluency task.

Table 1

Mean and Standard Deviation for the Average of Phonological and Semantic Fluency in Each One of the Grades

\begin{tabular}{lcccc}
\hline & \multicolumn{3}{c}{ Fluency } \\
\cline { 2 - 5 } Grade & \multicolumn{2}{c}{ Semantics } & \multicolumn{2}{c}{ Phonology } \\
\cline { 2 - 5 } & $M$ & $S D$ & $M$ & $S D$ \\
\hline $3^{\text {rd }}$ Grade & 11.17 & 1.99 & 4.77 & 1.72 \\
$5^{\text {th }}$ Grade & 13.06 & 2.46 & 7.32 & 2.42 \\
$7^{\text {th }}$ Grade & 13.69 & 2.29 & 7.92 & 2.05 \\
\hline
\end{tabular}

The average amount of examples given for the semantic fluency categories (corresponding to the fluency of animals, fruits and vegetables, body parts, transports, musical instruments and clothing) was calculated for each participant, as well as the average number of examples given 
for each phonological fluency phoneme (corresponding to the fluency of $/ \mathrm{f} /, \mathrm{a} / \mathrm{a}$ and $/ \mathrm{s} /$ ). The first analysis reveals statistically significant differences in the performance in fluency tasks in favour of the semantic fluency, $F_{(1,83)}=502.30$; $\mathrm{MSE}=3.02 ; p<.001 ; \eta 2=.86$. It also indicates significant differences by grade, $F_{(2,83)}=22.00$;
MSE $=6.19 ; p<.001 ; \eta 2=.35$. The post-hoc analysis, using the Bonferroni method, indicates that the students from $7^{\text {th }}$ grade do not significantly differ from those of $5^{\text {th }}$, but both grades differ significantly from those of $3^{\text {rd }}(p<.001)$. In the same way, the analysis did not detect interaction effects, $F_{(2,83)}=0.68 ; \mathrm{MSE}=3.02 ; p=$ $.51 ; \eta 2=.02$.

Table 2

Means and Standard Deviations in the Field of LT and IO in Each One of the Grades Assessed

Semantic domain

Grade

LT IO

\begin{tabular}{lcccc} 
& $M$ & $S D$ & $M$ & $S D$ \\
\hline $3^{\text {rd }}$ grade & 13.17 & 2.37 & 9.17 & 2.02 \\
$5^{\text {th }}$ grade & 15.76 & 3.32 & 10.36 & 2.30 \\
$7^{\text {th }}$ grade & 16.80 & 3.32 & 10.59 & 1.97
\end{tabular}

The results of the second analysis are presented in Table 2, and show the performance for the different domains in the different grades in semantic fluency tasks. The average amount of examples produced for each area was calculated for each participant. The LT domain comprises the categories of animals, fruit and vegetables along with body parts, while the IO domain comprises transports, clothing and musical instruments. This analysis shows a significant effect for the semantic domain, $F_{(1.83)}=341.228$; MSE $=3.381 ; p<.001 ; \eta 2=.804$. The children produce a greater amount of examples for LT than for IO. There are also statistically significant differences by grade, $F_{(2.83)}=10.584$; MSE $=9.992 ; p<.001 ; \eta 2=.203$. The amount of examples recovered increases for students from higher grades. The post-hoc analysis (Bonferroni method) allows seeing that $3^{\text {rd }}$ grade children significantly differ from those of $5^{\text {th }}$ grade $(p<.01)$ and $7^{\text {th }}$ grade $(p<.001)$, while there is no great difference in performance between $5^{\text {th }}$ and $7^{\text {th }}$. On the other hand, the domain and grade interaction is also significant, $F_{(2.83)}=5.693$; $\mathrm{MSE}=3.381 ; p<.01 ; \eta 2=.121$. Just like in the analysis by grade, the students from $3^{\text {rd }}$ grade are only dissociated from $5^{\text {th }}(p<.05)$ and $7^{\text {th }}(p<.05)$ in the amount of examples recovered for the LT domain, while students from $5^{\text {th }}$ and $7^{\text {th }}$ grades do not produce differences in the amount of examples recovered for this domain.

\section{Discussion}

The aim of this work was to obtain information about the performance of Argentinean school-age children in verbal fluency tasks. With this goal, data was obtained for SVF (animals, fruit/vegetables, body parts, means of transports, musical instruments and clothing) and for PVF (FAS test)

Just as in previous studies, the data obtained from the Argentinean population shows that school-age children improve their performance as they get older and attain a better performance in SVF than in PVF (Brocki \& Bohlin, 2004; García et al., 2012; García Coni \& Vivas, 2014; Matute et al., 2004; Valencia et al., 2000). In this sample, an increase in the amount of correct answers is seen, for both tasks, from $3^{\text {rd }}$ to $5^{\text {th }}$ grade. From $5^{\text {th }}$ grade onwards, the performance in both tasks is no longer statistically significant. 
In regards to the SVF, the average number of answers obtained for the animal category for $5^{\text {th }}$ grade children is equivalent to the one reported for Argentinean adults under 45 years old and with incomplete primary studies (Butman, Allegri, Harris, \& Drake, 2000). However, in the PVF, although there are no significant differences between $5^{\text {th }}$ and $7^{\text {th }}$, an increase in the amount of responses given for the phonemes $/ \mathrm{a} /$ and $/ \mathrm{s} /$ is seen. Unlike what happens with the children in the SVF, the data is not comparable with what is reported for our adult population (Butman et al., 2000). This may be because, with adults, the phoneme /p/ was evaluated. However, bearing in mind that the performance of the children evaluated in our sample is lower; we consider that the difference found in the performance in both verbal fluencies can be explained by the level of maturity of the cognitive systems involved in each one of the tasks. In the SVF, examples of a single category, provided beforehand by the evaluator (for example, animals), must be recovered. This means that the search is limited to recovering the items belonging to a familiar semantic category for the children. Therefore, in the SVF tasks, the executive function mechanisms, which are still developing in children of this age, do not have the same impact as the PVF tasks where the search the evaluated student must do is not limited to a single category and, as such, they must cover a larger amount of subcategories. To do this, children need to make an inter-category search. In addition, they must apply a search criterion which is not solely semantic, as occurs in the SVF, but also the linguistic organization of the items. Because of this, the PVF task is more difficult for children as they must activate inhibition mechanisms to perform the task and thus avoid the production of semantically incorrect related forms for the task (Arán-Filippetti, 2011). These strategic search mechanisms and inhibition mechanisms, sustained by the frontal lobe, would seem to be automatic both during the cognitive development and also in the formal schooling process of the children. As a result, older children perform better searches than younger ones, which is reflected both in the in- crease in the amount of items produced and also in the accuracy of the items chosen. That is to say, the students from $7^{\text {th }}$ grade present a lower amount of intrusions, for example, of proper nouns in PVF tasks.

In the framework of infant neuropsychological evaluations, phonological fluency tasks provide reliable means in the detection of attention disorders, as this task requires the person being evaluated to keep a sustained attention for prolonged periods of time while different vocabulary search strategies are implemented. The children who have attention deficit hyperactivity disorder (ADHD) tend to have results that are well below average in these tasks, as the period they keep attention for is greatly reduced (Grodzinsky \& Diamond, 1992). Likewise, this task is also important in the evaluation of children with dyslexia, as it is a useful means to diagnose and follow-up on the treatment implemented. (Cohen, Morgan, Vaughn, Riccio, \& Hall, 1999; Reiter, Tucha, \& Lange, 2005).

Unlike other projects that have been done for our population, which have evaluated children's performance in a single semantic category (specifically animals); in our work we test several categories from the LT domain and others from IO domain to be able to identify semantic differences in the infant processing skills.

Our data shows differences in processing in favour of the LT domain. In line with the results obtained by Valencia et al. (2000), the categories of this domain are natural categories and, therefore, fewer years of schooling may be needed to develop them. The data shows that $3^{\text {rd }}$ grade children differ significantly from $5^{\text {th }}$ and $7^{\text {th }}$ only in the LT domain, but this does not happen between $5^{\text {th }}$ and $7^{\text {th }}$, which have a similar performance. However, for the IO domain no differences are detected between the three groups, which show a lower performance than in the case of the other semantic domain.

Returning to what we said in the introduction, one of the questions that is still in up in the air is about when, during the development, children reach a similar performance to adults in verbal fluency tasks; our data lets us see that $5^{\text {th }}$ 
grade children reach a performance comparable with that of young adults with incomplete primary education in the semantic fluency task for the animals' category (sole category contemplated in adult research). Given that our sample is comprised by three non-consecutive groups, the results do not let us know with certainty when, during childhood development, they reach the same capacity of recovering examples from their semantic store as adults do. Therefore, it will be necessary to broaden the sample and include performance data from $4^{\text {th }}$ grade to establish more accurately the moment of semantic development culmination for the animal category.

In regards to the phonological fluency task, it is worth stating that the children of our study do not reach the same level as that of adult subjects evaluated in other works carried out with our population. Therefore, up to 12 years of age, the cognitive abilities involved in phonological fluency tasks are still being developed. To be able to have a more certain knowledge of the moment in which children and adults even out their performance in phonological fluency tasks, it is necessary to broaden the sample and evaluate older children and adolescents.

The dissociation found in the performance between SVF and PVF is in line with the findings of Hurks et al. (2006) and Matute et al. (2004), which state that phonological and semantic verbal fluency abilities are not jointly developed.

On the other hand, given that we do not have a standardized database for child population of our country, this work is of great relevance. This research forms part of a semantic fluency standardization project of diverse semantic categories in children (pre-school and primary aged children), adolescents (secondary school students) and adults.

This work, however, does have certain limitations. On one hand, the population studied is limited to an average population that attends a private school. As a result of this, the sample must be extended by evaluating students that attend public schools. Likewise, the parents' level of studies in our sample indicates that they belong to the middle class; hence information is needed from the other socioeconomic classes of our country (upper and lower).

Another limitation, bearing in mind the country's population diversity, is that our sample only represents the region of Buenos Aires and possibly just one part of the Province of Buenos Aires. Students from the rest of the regions of our country (north and south) need to be evaluated to identify possible dissociations in regards to the regions.

In this work, the analysis is focused on identifying possible differences in terms of the amount of examples recovered. As a possible line for future research, a cluster analysis could be done (Troyer et al., 1998) to get to know the semantic organization of each one of the categories evaluated with the fluencies.

\section{References}

Albanese, E., Capitani, E., Barbarotto, R., \& Laiacona, M. (2000). Semantic category dissociations, familiarity and gender. Cortex, 36, 733-746.

Anderson, V., Northam, E., Hendy, J., \& Wrenall, J. (2001). Developmental Neuropsychology: A clinical approach. New York: Psychology Press.

Arán-Filippetti, V. (2011). Fluidez verbal según tipo de tarea, intervalo de tiempo y estrato socioeconómico, en niños escolarizados. Anales de Psicología, 27(3), 816-826.

Ardila, A., Rosselli, M., Matute, E., \& Guajardo, G. (2005). The influence of parents educational level on the development of executive functions. Developmental Neuropsychology, 28, 539-560. doi:10.1207/s15326942dn2801_5

Binetti, G., Magni, E., Cappa, S. F., Padovani, A., Bianchetti, A., \& Trabucchi, M. (1995). Semantic memory in Alzheimer's disease: An analysis of category fluency. Journal of Clinical and Experimental Neuropsychology, 17, 82-89.

Brocki, K. C., \& Bohlin, G. (2004). Executive functions in children aged 6 to 13: A dimensional and developmental study. Developmental Neuropsychology, 26, 571-593. doi:10.1207/ s15326942dn2602_3

Buriel, Y., Gramunt, N., Bohm, P., Rodes, E., \& Pena-Casanova, J. (2004). Verbal fluency: Preliminary normative data in a Spanish sample of 
young adults (20-49 years of age). Neurología, 19(4), 153-159.

Butman, J., Allegri, R. F., Harris, P., \& Drake, M. (2000). Fluencia verbal en español. Medicina, $60,561-564$.

Capitani, E., Laiacona, M., \& Barbarotto, R. (1999). Gender affects Word retrieval of certain categories in semantic fluency tasks. Cortex, 35, 273 278. doi:10.1016/S0010-9452(08)70800-1

Casals-Coll, M., Sánchez-Benavides, G., Quintana, M., Manero, R. M., Rognoni, T., Calvo, L., ...Peña-Casanova, J. (2013). Estudios normativos españoles en población adulta joven (proyecto NEURONORMA jóvenes): normas para los test de fluencia verbal. Neurología, 28(1), 33-40.

Cohen, M. J., Morgan, A. M., Vaughn, M., Riccio, C. A., \& Hall, J. (1999). Verbal fluency in children: Developmental issues and differential validity in distinguishing children with attention-deficit hyperactivity disorder and two subtypes of dyslexia. Archives of Clinical Neuropsychology, 14(5), 433-443. doi:10.1016/S0887-6177(98)00038-9

Comesaña, A., \& García Coni, A. (2013). Análisis de tareas de fluidez verbal en enfermos de Alzheimer y adultos sanos. Temas em Psicologia, 21(1), 269-281. doi:10.9788/TP2013.1-19

Chertkow, H., \& Bub, D. (1990). Semantic memory loss in dementia of Alzheimer's type. What do various measures measure? Brain, 113, 397-417.

Fernández, A. L., Marino, J. C., \& Alderete, A. M. (2004). Valores normativos en la prueba de fluidez verbal-animales sobre una muestra de 251 adultos argentinos. Revista Argentina de Neuropsicología, 4, 12-22.

Galaverna, F. S., Marino, J. C., \& Abraham, M. (2008). Estudio Comparativo de la Organización Semántica entre Sujetos con Trastorno Esquizofrénico y Sujetos Normales. Revista Neuropsicología, Neuropsiquiatría y Neurociencias, 8(2), 59-71.

García, E., Rodríguez, C., Martín, R., Jiménez, J. E., Hernández, S., \& Díaz, A. (2012). Test de Fluidez Verbal: datos normativos y desarrollo evolutivo en el alumnado de primaria. European Journal of Education and Psychology, 5(1), 53-64.

García Coni, A., \& Vivas, J. (2014). Estrategias ejecutivas de búsqueda, recuperación y cambio en la fluidez verbal. Evaluar, 14, 15-42.
Grodzinsky, G. M., \& Diamond, R. (1992). Frontal lobe functioning in boys with attention-deficit hyperactivity disorder. Developmental Neuropsychology, 8, 427-445. doi:10.1080/87565649209540536

Halpern, D. F. (1992). Sex differences in cognitive abilities ( $2^{\text {nd }}$ ed.). Hillsdale, NJ: Erlbaum.

Henry, J. D., \& Crawford, J. R. (2004). A metaanalytic of verbal fluency performance following focal cortical lesions. Neuropsychology, 18, 284-295. doi:10.1037/0894-4105.18.2.284

Henry, J. D., Crawford, J. R., \& Phillips, L. H. (2004). Verbal fluency performance in dementia of the Alzheimer's type: A meta-analysis. Neuropsychologia, 42, 1212-1222.

Hirshorn, E., \& Thompson-Schill, S. (2006). Role of the left inferior frontal gyrus in covert word retrieval: Neural correlates of switching during verbal fluency. Neuropsychologia, 44, 2547-2557. doi:10.1016/j.neuropsychologia.2006.03.035

Hodges, J. R., \& Patterson, K. (1997). Semantic memory disorders. Trends in Cognitive Sciences, 1(2), 68-72. doi:10.1016/S1364-6613(97)01022-X

Hurks, P. P. M., Hendriksen, J. G. M., Vles, J. S. H., Kalff, A. C., Feron, F. J. M., Kroes, M., ...Jolles, J. (2004). Verbal fluency over time as a measure of automatic and controlled processing in children with ADHD. Brain and Cognition, 55, $535-$ 544. doi:10.1016/j.bandc.2004.03.003

Hurks, P. P. M., Vles, J. S. H., Hendriksen, J. G. M., Kalff, A. C., Feron, F. J. M., Kroes, M., ...Jolles, J. (2006). Semantic category fluency versus initial letter fluency over 60 seconds as a measure of automatic and controlled processing in healthy school-aged children. Journal of Clinical and Experimental Neuropsychology, 28, 684-695. doi:http:// dx.doi.org/10.1080/13803390590954191

Kempler, D., Teng, E. L., Dick, M., Taussig, I. M., \& Davis, D. S. (1998). The effects of age, education, and ethnicity on verbal fluency. Journal of the International Neuropsychological Society, 4, 531-538. doi:http://dx.doi.org/10.1017/ S1355617798466013

Klenberg, L., Korkman, M., \& Lahti-Nuuttila, P. (2001). Differential development of attention and executive functions in 3 to 12 years-old Finnish children. Developmental Neuropsychology, 20, 407-428. doi:http://dx.doi.org/10.1207/ S15326942DN2001_6 
Koren, R., Kofman, O., \& Berger, A. (2005). Analysis of word clustering in verbal fluency of school-aged children. Archives of Clinical Neuropsychology, 20, 1087-1104. doi:http:// dx.doi.org/10.1016/j.acn.2005.06.012

Laws, K. R. (1999). Gender afects latencies for naming living and nonliving things: implications for familiarity. Cortex, 35, 729-733.

Laws, K. R. (2004). Sex differences in lexical size across semantic categories. Personality and Invidual Differences, 36, 23-32. doi:http:// dx.doi.org/10.1016/S0191-8869(03)00048-5

Lezak, M. D., Howieson, D. B., \& Loring, D. W. (2004). Neuropsychological assessment. New York: Oxford University Press.

Lozano Gutiérrez, A., \& Ostrosky-Solís, F. (2006). Efecto de la edad y la escolaridad en la fluidez verbal semántica: datos normativos en población hispanohablante. Revista Mexicana de Psicología, 23(1), 37-44.

Marino, J., \& Alderete, A. M. (2010). Valores normativos de pruebas de fluidez verbal categoriales, fonológicas, gramaticales y combinadas y análisis comparativo de la capacidad de iniciación. Revista Neuropsicología, Neuropsiquiatría y Neurociencias, 10(1), 79-93.

Marino, J., \& Díaz-Fajreldines, H. (2011). Pruebas de fluidez verbal categoriales, fonológicas y gramaticales en la infancia: factores ejecutivos y semánticos. Revista Chilena de Neuropsicología, 6(1), 49-56.

Marra, C., Ferraccioli, M., \& Gainotti, G. (2007). Gender-related dissociations of categorical fluency in normal subjects and in subjects with Alzheimer's disease. Neuropsychology, 21(2), 207-211. doi:http://dx.doi.org/10.1037/08944105.21.2.207

Matute, E., Rosselli, M., Ardila, A., \& Morales, L. (2004). Verbal and non-verbal fluency in Spanish speaking children. Developmental Neuropsychology, 26, 647-660.

McKenna, P., \& Parry, R. (1994). Category-specificity in the naming of natural and man-made objects. Neuropsychological Rehabilitation, 4, 255-281. doi:10.1080/09602019408401461

Nieto, A., Galtier, I., Barroso, J., \& Espinosa, G. (2008). Fluencia verbal en niños españoles en edad escolar: estudio normativo piloto y análisis de las estrategias organizativas. Revista Neurologica, 46(1), 2-6.
Ollari, A., \& Diez, S. (2005). Neurobiología del envejecimiento. In O. Mangone, R. Allegri, R. Arizaga, \& J. Ollari (Eds.), Demencia: enfoque multidisciplinario (pp. 1-22). Buenos Aires: Polemos.

Ostrosky-Solís, F., \& Ardila, A. (1991). Un esquema de diagnóstico neuropsicológico: efectos socioculturales y su aplicación en el diagnóstico del daño cerebral. Revista Mexicana de Salud Mental, 14(4), 17-23.

Pekkala, S., Goral, M., Hyun, J., Obler, L. K., Erkinjuntti, T., \& \& Albert, M. (2009). Semantic verbal fluency in two contrasting languages. Clinical Linguistics \& Phonetics, 23(6), 431-445. doi:http://dx.doi. org/10.1080/02699200902839800

Ramírez, M., Ostrosky-Solís, F., Fernández, A., \& Ardila-Ardila, A. (2005). Fluidez verbal semántica en hispanohablantes: un análisis comparativo. Revista de Neurología, 41, 463-468.

Ratcliff, G., Ganguli, M., Chandra, V., Sharma, S., Belle, S., Seaberg, E., \& Pandav, R. (1998). Effects of literacy and education on measures of word fluency. Brain and Language, 61, 115-122. doi:http://dx.doi.org/10.1006/brln.1997.1858

Reiter, A., Tucha, O., \& Lange, K. W. (2005). Executive functions in children with dyslexia. Dyslexia, 11(2), 116-131. doi:http://dx.doi. org/10.1002/dys.289

Rodríguez-Aranda, C., \& Martinussen, M. (2006). Age-related differences in performance of phonemic verbal fluency measured by Controlled Oral Word Association Task (COWAT): A meta-analytic study. Developmental Neuropsychology, 30, 697-717.

Rosser, A., \& Hodges, J. R. (1994). Initial letter and semantic category fluency in Alzheimer's disease, Huntington's disease, and progressive supranuclear palsy. Journal of Neurology, Neurosurgery and Psychiatry, 57, 1389-1394.

Sautú, R. (1991). Oportunidades ocupacionales diferenciales por sexo en Argentina: 1970/1980. Paper presented at the Estudios del Trabajo, Buenos Aires, Argentina.

Soriano, F., Fumagalli, J., Shalóm, D., Carden, J., Borovinsky, G., Manes, F., \& Martínez-Cuitiño, M. (2015). Sex differences in a semantic fluency task. East European Journal of Psycholinguistic 2(1), 134-140. 
Stuss, D. T., Alexander, M. P., Hamer, L., Palumbo, C., Dempster, R., Binns, M., ...Izukawa, D. (1998). The effects of focal anterior and posterior brain lesions on verbal fluency. Journal of the International Neuropsychological Society, 4, 265-278

Tombaugh, T. N., Kozak, J., \& Rees, L. (1999). Normative data stratified by age and education for two measures of verbal fluency: FAS and animal naming. Archives of Clinical Neuropsychology, 14(2), 167-177. doi:http://dx.doi.org/10.1093/ $\operatorname{arclin} / 14.2 .167$

Troyer, A., Moscovitch, M., Winocur, G., Alexander, M. P., \& Stuss, D. T. (1998). Clustering and switching on verbal fluency: The effects of focal frontal and temporal lobes lesions. Neuropsychologia, 36(6), 499-504. doi:http://dx.doi. org/10.1016/S0028-3932(97)00152-8

Valencia, N. J., Laserna, J. A., Pérez-García, M., Orozco, C., Miñán, M., Garrido, C., ...Morente, G. (2000). Influencia de la escolaridad y el sexo sobre la ejecución en el fas, nombrar animales y nombrar frutas. Psicología Conductual, 8(2), $283-295$
Villodre, R., Sánchez-Alfonso, A., Brines, L., Núñez, A. B., Chirivella, J., Ferri, J., \& Noé, E. (2006). Verbal fluency tasks in a Spanish sample of young adults (20-49 years of age): normative data of clustering and switching strategies. $\mathrm{Neu}$ rología, 21(3), 124-130.

Zanin, L., Ledezma, C., Galarsi, F., \& De Bortoli, M. A. (2010). Fluidez verbal en una muestra de 227 sujetos de la región Cuyo (Argentina). Fundamentos en Humanidades, 21(1), 207-219.
Recebido: $15 / 11 / 2015$

$1^{a}$ revisão: 08/04/2016

$2^{a}$ revisão: 13/05/2016

Aceite final: 17/05/2016 